\title{
Obesity and brain illness: from cognitive and psychological evidences to obesity paradox
}

This article was published in the following Dove Press journal:

Diabetes, Metabolic Syndrome and Obesity:Targets and Therapy

Number of times this article has been viewed

\author{
Vincenzo Monda ${ }^{1, *}$ \\ Marco La Marra ${ }^{1, *}$ \\ Raffaella Perrella ${ }^{2}$ \\ Giorgio Caviglia ${ }^{2}$ \\ Alessandro lavarone ${ }^{3}$ \\ Sergio Chieffi' \\ Giovanni Messina ${ }^{4}$ \\ Marco Carotenuto 5 \\ Marcellino Monda' \\ Antonietta Messina' \\ 'Department of Experimental \\ Medicine, Section of Human \\ Physiology, University of Campania \\ Luigi Vanvitelli, Naples, Italy; \\ ${ }^{2}$ Neurological and Stroke Unit, \\ CTO Hospital, AORN "Ospedali dei \\ Colli”, Naples, Italy; ${ }^{3}$ Department \\ of Psychology, University of \\ Campania Luigi Vanvitelli, Naples, \\ Italy; ${ }^{4}$ Department of Clinical and \\ Experimental Medicine, University of \\ Foggia, Foggia, Italy; ${ }^{5} \mathrm{Clinic}$ of Child \\ and Adolescent Neuropsychiatry, \\ Department of Mental Health, Physical \\ and Preventive Medicine, University of \\ Campania Luigi Vanvitelli, Naples, Italy \\ *These authors contributed equally to \\ this work
}

Correspondence: Giovanni Messina Department of Clinical and Experimental Medicine, University of Foggia, Via L Pinto, 7 I I22 Foggia, Italy Email giovanni.messina@unifg.it
Abstract: Recent findings showed that obesity represents an additional risk factor to developing brain illness such as cognitive impairments and psychopathological disorders. However, some benefits of overweight in the elderly have been identified and an "obesity paradox" has been shown. Currently, it is still unknown how obesity and brain functioning could be linked, and the process by which body fat independently injures cognitive abilities and psychological wellbeing remains unclear. To establish the independent role of obesity on cognitive abilities and mental health, clarifying the role played by several factors and understanding their interaction is essential. In this review, we discuss the relationship between obesity and brain illness and underline the role played by confounders and other covariates to determine this link.

Keywords: obesity, cognitive decline, mood disorders, obesity paradox

\section{Introduction}

In the past decades, worldwide obesity gradually increased and World Health Organization formally recognized this condition as a global epidemic. ${ }^{1,2}$

Recent readings estimate worldwide incidence of obese adults at $10.8 \%$ for men and $14.9 \%$ for women, increasing from 857 million in 1980 to 2.1 billion in 2013 for both developing and developed countries. In the same time frame, overweight people increased from $28.8 \%$ to $36.9 \%$ (men) and from $29.8 \%$ to $38 \%$ (women). However, different sex and age patterns between countries are observed. The prevalence is also rising in children and adolescents, increasing from $8.1 \%$ in 1980 to $12.9 \%$ in 2013 in boys and $8.4 \%$ to $13.4 \%$ in girls. ${ }^{3}$

Obesity negatively affects most bodily systems and boosts the risk of many chronic diseases, including type 2 diabetes, metabolic syndrome, hypertension, dyslipidemia, hyperinsulinemia, coronary artery disease, cardiovascular disease, osteoarthritis, chronic kidney disease, many forms of cancer (e.g., endometrial, esophageal, renal cell, pancreatic, ovarian, breast, colorectal, thyroid, malignant melanoma, etc.), nonalcoholic steatohepatitis, sleep apnea, depression and other psychiatric disorders. ${ }^{4-9}$

Furthermore, recent findings showed that obesity may also affect cognitive function, and higher body mass index (BMI), especially in midlife, might increase the risk of developing dementia, or other cognitive impairments, later in life. ${ }^{10-13}$

However, despite these findings, some benefits of overweight in the elderly have been identified, ${ }^{14}$ and an "obesity paradox" in the past years has been shown. ${ }^{15}$

Currently, it is still unknown how weight increase and brain functioning could be linked, and the process by which obesity injures cognitive abilities and psychological well-being remains unclear. 
To establish the independent role of obesity on brain physiology, it is necessary to clarify the role played by several factors and understand their interaction, which is essential to plan future studies.

This review, conducted in line with the American Psychiatric Association practice guidelines, focuses on the relationship between obesity, cognitive decline (CD) and psychological disorders and underlines the role played by confounders and other covariates to determine this link.

\section{Obesity and CD}

To better understand the role played by obesity to affect cognitive functioning is essential to examine how weight increase interacts with brain physiology.

Structural integrity is reflected by brain substructure volumes and represents a major hallmark of underlying neuronal health. Tissue loss occurs with normal aging, but it is more marked in dementia cases. ${ }^{16,17}$

Recent findings showed that obesity additively afflicts the brain structure of cognitively impaired patients and is linked to poor brain volumes even in cognitively normal elderly subjects. ${ }^{18}$

In a longitudinal study group from overweight and obese female patients, temporal lobe atrophy was estimated from $13 \%$ to $16 \%$ for each BMI unit increase. ${ }^{19}$ In a structural brain mapping cohort study of 700 cognitively impaired patients (mild cognitive impairment [MCI] and Alzheimer's disease [AD]), higher BMI was related to decreased brain volume in frontal, temporal, parietal, and occipital lobe regions, proving an additional burden on the brain structure. Further, whole brain analysis estimated brain tissue reduction from $0.5 \%$ to $1.5 \%$ for each BMI unit increase, even after controlling for relevant confounders (i.e., sex, age, level of education), and $\mathrm{AD}$ caused widespread brain volume deficits and ventricular expansion (other features of brain tissue loss) compared with MCI. ${ }^{20}$

Brain scanning studies demonstrated that obese individuals had significantly lower gray matter density in the post-central gyrus, frontal lobe, putamen, and middle frontal gyrus when compared with normal weight. ${ }^{21}$

Greater body adiposity in otherwise healthy subjects was related with lower brain volumes in hippocampus area, orbital frontal cortex and parietal lobes.

Cross-sectional studies showed that elevated waist-hip ratio and greater BMI were linked to reduced hippocampal volume and tissue loss of temporal lobe..$^{22-24}$

A further analysis in over 1400 healthy Japanese showed negative correlation between brain volume and obesity, high- lighting lower brain gray matter ratio of temporal, occipital and frontal lobes and the anterior lobe of cerebellum. ${ }^{25}$

Several studies have found that obesity in midlife is related with an increased risk of $\mathrm{CD}$ in the elderly, and, according to these findings, consistent neuropathological studies showed either hippocampal brain atrophy or executive disfunction. ${ }^{26 ; 116-119}$ It is well recognized that hippocampal formation played a key role in learning and memory, ${ }^{27,28}$ it is particularly affected by aging ${ }^{29-31}$ and that low volume of this region predicts cognitive impairment and dementia in general people. ${ }^{32-37}$

However, the exact underlying mechanisms by which obesity increases the risk of AD remains to be fully understood, but some explanations are available.

Neuropathological features of AD, such as amyloid plaques and neurofibrillary tangles, ${ }^{38}$ are even more stated in elderly obese people when compared with normal-weight subjects. In a cohort study, greater levels of $\beta$-amyloid, the main component of amyloid plaques, protein precursor and expression of tau, were present in the hippocampal region of morbidly obese patients without cognitive damage when compared with non-obese controls. ${ }^{39}$

A possible connection between midlife obesity and development of AD in the elderly is represented by increased levels of adipose tissue, which could modify $\beta$-amyloid metabolism. Plasma amyloid proteins have been found in obesity, ${ }^{40,41}$ and it is suggestive of increased risk of $\mathrm{AD} .^{42}$

Furthermore, high-fat diet may independently increase either body fat or dementia risk. ${ }^{43}$ In a prospective study from 939 individuals aged $\geq 65$ years, greater caloric intake was related to higher AD risk in the subsequent 6.3-year follow-up. ${ }^{44}$ High-fat diet (fatty acids and sugars) may also interact with brain physiology, harming the integrity of blood-brain barrier (BBB), ${ }^{45}$ which plays a key role in protecting the central nervous system (CNS) from bloodborne toxins. ${ }^{46} \mathrm{AD}$ and vascular dementia $(\mathrm{VaD})$ are linked with BBB dysfunction, ${ }^{47}$ and longitudinal study showed that midlife obesity was also correlated with lower BBB integrity. ${ }^{48}$

Higher levels of white adipose tissue could increase systemic inflammation and may provide $\mathrm{CD}$ and dementia. ${ }^{49}$ Adipocytes, lymphocytes and macrophages leading to production of pro-inflammatory cytokines and subsequent increase in tumor necrosis factor- $\alpha .^{50-53,115}$ Indeed, central inflammation is observed after high-fat feeding, especially in the hypothalamus region. ${ }^{54}$ Further, systemic inflammation has been shown to be linked to vascular disease, ${ }^{55}$ obesity, poorer cognitive performance and dementia. ${ }^{56,57}$ It was 
demonstrated $^{58}$ that the outcomes of metabolic syndrome on cognitive performance were mediated by inflammation, and that combined effects of high inflammation and metabolic syndrome had a greater risk of CD. However, the direction of the associations between inflammation and dementia is unclear. ${ }^{59}$

Finally, the effects of obesity on brain physiology are further observed in principal mediators of the CNS, such as microglia and astrocytes.

\section{Obesity and psychopathology}

Several studies suggest that subjects with severe psychiatric disorders are more likely than general population to be obese. ${ }^{60}$ However, the link between body fat and psychiatric illness is widely discussed.

There are several studies that account for the risk of psychiatric disorders in obese individuals such as mood disorders, anxiety disorders, low self-esteem, body dissatisfaction, eating disorders and emotional problems. ${ }^{61,62}$ However, an extensive body of literature shows that mood disorders are most frequently related to obesity, and the incident risk of lifetime depression is significantly higher in obese persons when compared with non-obese peers, with a range from $29 \%$ to $56 \%$. $^{63-65}$

In a study performed with more than 40,000 people, the relationship between obesity and depression varied by sex and obese men, compared with normal-weight people, reported less symptoms of major depression and suicidal ideation. A different pattern was seen for women that was $37 \%$ more likely to report depressive symptom when compared with normal-weight peers. ${ }^{66}$

However, with regard to the direction of relationships between obesity and psychopathology, the studies failed to find clinically significant results. Studies that investigated whether obesity precedes depression or whether an existing mood disturbance predisposed to weight increase showed conflicting results.

In a nationally representative adolescent sample, obesity condition did not increase depression incidence 1 year later. However, depression at baseline doubled the risk of developing obesity at follow-up. ${ }^{67}$

Apparently, results from longitudinal studies suggest that depression precedes obesity in adolescent girls, but not boys, and that obesity precedes depression in older adults. In a sample of 1037 New Zealanders, boys who were depressed at age 18 or 21 were less likely to be obese at age 26 . Girls with late adolescent depression, however, were twice as likely to be obese at age $26 .^{68}$
However, other studies showed that obesity is not strongly associated with depression, or any abnormal personality characteristics and psychological traits are more widely varied within the population of obese individuals than between obese and non-obese. ${ }^{69-73}$

The reason for controversial results seems to be a lack of consensus about how to measure psychological functioning, and a growing body of studies reminds us of the importance of considering the role played by co-morbidity of morbid obesity.

Actually, further research on this issue is needed.

\section{The obesity paradox}

Several studies have provided empirical evidence that obesity in midlife represents a risk factor for cognitive diseases later in life, such as MCI, VaD and AD. ${ }^{74-78}$

Higher midlife BMI is heavily predictive of both $\mathrm{AD}$ and $\mathrm{VaD}$, independent of other comorbidities (e.g., stroke, cardiovascular diseases and diabetes), and compared with normalweight individuals, obesity at age $40-45$ years increases the risk of developing dementia by $74 \%$ in the elderly.

In a prospective cohort study, high BMI assessed in middle age was independently linked with cognitive impairment in a sample aged 33-62 years in the subsequent 5-year follow-up, ${ }^{79}$ and subjects with BMI above the third quartile during middle age had $59 \%$ greater risk of suffering dementia during old age.

These results collectively suggest that midlife obesity is a strong predictor of dementia in the elderly, and being obese in middle age may increase the risk for functional impairment and brain pathology. ${ }^{80}$

Despite these findings, ${ }^{81,82}$ other studies have shown no association or even negative correlations between obesity and cognitive impairment in the elderly. ${ }^{83-85}$

A substantial part of scientific literature in this area underlines that body fat, traditionally considered dangerous for health, might predict survival in the elderly and that even low BMI during middle age could be linked to CD in old age. ${ }^{86-88}$

Some findings support this dissociation, highlighting an "obesity paradox". ${ }^{89}$

Continuous BMI was not linked to cognitive impairment in some studies, ${ }^{90-93}$ and high BMI, assessed in late life, was not related to increased risk of CD. ${ }^{94}$ In a sample of 169 adults aged $\geq 68$ years, greater BMI reduced risk of $C D$ when compared with lower BMI subjects $(<23)$ in a 5-year follow-up. ${ }^{95}$ In a sample of 1393 elderly subjects, continuous BMI and MCI were not linked..$^{96}$ In an 8-year prospective investigation of 1351 subjects, higher BMI was not associated with 
increased dementia risk. ${ }^{97} \mathrm{In}$ a research study of 1302 patients (mean age $77.71 \pm 6.86$ years), of which 905 (69.5\%) without $\mathrm{CD}$ and 397 (30.5\%) had CD, higher BMI scores reduced the risk of cognitive disorder. ${ }^{98}$ Finally, underweight condition in late life (BMI <20) increased dementia risk by $60 \%$, while being obese (BMI $>30$ ) was linked with a reduced risk of cognitive impairments.

To summarize, the studies performed in middle age show a relationship between high BMI and dementia risk, whereas those in the elderly differ. Apparently, risk estimates in middle age reversed when assessed in late life.

A recent meta-analyses performed with extensive followup (ranging from 3.2 to 36.0 years) showed that low BMI in midlife, compared with normal BMI, increased 1.96 times the risk of developing $\mathrm{AD}$ in the elderly. The relative risk to develop AD for obese midlife BMI was 2.04. Furthermore, compared with normal BMI, overweight midlife could be associated with $35 \%$ increased risk of developing $\mathrm{AD}$ and $33 \%$ of developing $\mathrm{VaD}$ in late life. These findings overall suggest that underweight, overweight and obesity in midlife increase dementia risk and that predictive ability of BMI varied over time.

Consistent with previous systematic reviews and meta-analysis from body weight and dementia, ${ }^{99}$ the risks appear higher for underweight and obese BMI, suggesting a U-shaped relationship, a curvilinear association between midlife BMI and late-life dementia.

However, these inconsistencies and paradoxical findings may have several explanations.

According to Clinical Guidelines on the identification, evaluation and treatment of overweight and obesity in adults (1998), BMI $\leq 18.5 \mathrm{~kg} / \mathrm{m}^{2}$ underweight condition, from 18.5 to $24.9 \mathrm{~kg} / \mathrm{m}^{2}$ normal- or healthy-weight condition, from 25 to $29.9 \mathrm{~kg} / \mathrm{m}^{2}$ overweight, $\geq 30 \mathrm{~kg} / \mathrm{m}^{2}$ obesity and $\geq 40 \mathrm{~kg} / \mathrm{m}^{2}$ morbid obesity. This index was first described by Adolphe Quetelet but involved some limitations. ${ }^{100}$

Ethnicity and age, for example, affect this index because fat-free mass ratio decreases with age, especially among women. ${ }^{101}$ Aging process implied that lean body mass decreases, while adipose tissue increases without weight gain. Therefore, this ratio may not be captured by BMI and not represent, in the elderly, a reliable index of adiposity. ${ }^{102,103}$ In other words, BMI may underestimate adiposity because with aging, lean body mass is replaced by fat. ${ }^{104}$ Thus, this index is a better measure of adiposity only for younger people while, during old age, it is possible to report low BMI despite relatively high body fat. The link between increased adiposity and dementia may be weaker among older subjects who may have more body fat despite low body weight and cloud the relationship between obesity and dementia in older samples.

Alternative anthropometric tools to assess obesity in the elderly could be more effective. It has been reported that the highest quintile of sagittal abdominal diameter, evaluated in midlife, was related with a three fold increased dementia risk. Waist circumference and waist: hip ratio have been proposed as a better adiposity marker in old age ${ }^{105}$ and are also related to higher dementia risk. ${ }^{44}$ Therefore, it has been suggested that low late-life BMI and waist circumference represent potentially useful preclinical markers for MCI and $\mathrm{AD} .{ }^{106}$

Another possible explanation of conflicting results is that rapid weight loss could precede diagnosis of $\mathrm{AD}$ and general cognitive impairment by several years. ${ }^{107-109} \mathrm{Clinical}$ data suggest that weight loss precedes dementia diagnosis ${ }^{92,93}$ and in dementia onset, obese patients lose $\sim 50 \%$ of their pre-dementia weight. ${ }^{110,111}$ This implies that BMI effects on dementia may be more accurately estimated at midlife than in old age ${ }^{7,24}$ because it would reflect a more valid perspective of a person's lifelong exposure to body fat. ${ }^{59}$

It is now known that underlying neuropathological changes characterized by extracellular amyloid plaques and intracellular neurofibrillary tangles may be observed many years in advance of the onset of clinical symptoms of AD. As a result of $\mathrm{AD}$, BMI may decrease and emerge earlier than cognitive symptoms.

Furthermore, weight loss occurs with a lot of comorbidities in older age $\mathrm{e}^{12-114}$ and reflects poor health. Higher midlife BMI increases dementia risk; in old age, increased BMI could be a global marker of decreased risk. In agreement with these hypotheses, being overweight and obese in later life seems to be a protective factor from dementia. Nevertheless, many studies are required.

\section{Conclusion}

It is unclear whether obesity increases cognitive impairments independently from other risk factors, given that some experimental studies are limited by study design, variable follow-up and limited account of comorbidities.

Although previous findings have shown negative association between obesity and age-related $\mathrm{CD}$, studies performed with appropriate exclusion criteria and accurate adjustment for potential collinearity seem to support the relationship.

Given the need to achieve synergies between research activities, future studies should focus on the independent role of obesity on brain functioning, taking into account a large number of covariates, such as sex, lifestyle factors (diet, physical activity, level of education, smoking, alcohol consumption), neurological disorders, mental diseases, vascular 
diseases, inflammatory processes, hypertension, diabetes and leptin dysregulation.

To better understand the exclusive role of obesity in enhancing $\mathrm{CD}$ and psychological diseases, there is a need to improve the study design by implementing clear exclusion criteria, adequate comparison groups, multivariate statistical technique and appropriate assessment of cognitive domains and psychological functions.

In this paper, we provided some insights about confounders and emphasized the need for more multivariate research.

\section{Author contributions}

All authors contributed toward data analysis, drafting and revising the paper and agree to be accountable for all aspects of the work.

\section{Disclosure}

The authors report no conflicts of interest in this work.

\section{References}

1. Caballero B. The global epidemic of obesity: an overview. Epidemiol Rev. 2007;29:1-5.

2. Mitchell NS, Catenacci VA, Wyatt HR, Hill JO. Obesity: overview of an epidemic. Psychiatr Clin North Am. 2011;34:717-732.

3. Ng M, Fleming T, Robinson M, et al. Global, regional, and national prevalence of overweight and obesity in children and adults during 1980-2013: a systematic analysis for the Global Burden of Disease Study 2013. Lancet. 2014;384(9945):766-781.

4. World Health Organization. Obesity and Overweight [Fact Sheet]; 2011.

5. Qiu C, Winblad B, Fratiglioni L. The age-dependent relation of blood pressure to cognitive function and dementia. Lancet Neurol. 2005, 4(8):487-499.

6. Panza F, D'Introno A, Colacicco AM, et al. Lipid metabolism in cognitive declineand dementia. Brain Res Rev. 2006;51(2):275-292.

7. Whitmer RA, Gunderson EP, Barrett-Connor E, Quesenberry CP Jr, Yaffe K. Obesity in middle age and future risk of dementia: a 27 year longitudinal population based study. BMJ. 2005;330(7504):1360.

8. Grimley EJ, Areosa SA. Effect of the treatmentof type II diabetes mellitus on the development of cognitive impairment and dementia. Cochrane Database Syst Rev. 2003;1:CD003804.

9. Marra L, Cantile M, Scognamiglio G, et al. Deregulation of HOX B13 expression in urinary bladder cancer progression. Curr Med Chem. 2013;20(6):833-839.

10. Gustafson D, Rothenberg E, Blennow K, Steen B, Skoog I. An 18-year follow-up of overweight and risk of Alzheimer disease. Arch Intern Med. 2003;163(13):1524-1528.

11. Rosengren A, Skoog I, Gustafson D, Wilhelmsen L. Body mass index, other cardiovascular risk factors, and hospitalization for dementia. Arch Intern Med. 2005;165(3):321-326.

12. Whitmer RA, Gustafson DR, Barrett-Connor E, Haan MN, Gunderson EP, Yaffe K. Central obesity and increased risk of dementia more than three decades later. Neurology. 2008;71(14):1057-1064.

13. Beydoun MA, Beydoun HA, Wang Y. Obesity and central obesity as risk factors for incident dementia and its subtypes: a systematic review and meta-analysis. Obes Rev. 2008; 9(3):204-218.

14. Atti AR, Palmer K, Volpato S, Winblad B, De Ronchi D, Fratiglioni L. Late-life body mass index and dementia incidence: nine-year follow-up data from the Kungsholmen Project. J Am Geriatr Soc, 2008;56(1):111-116.
15. Fitzpatrick AL, Kuller LH, Lopez OL, et al. Midlife and late-life obesity and the risk of dementia: cardiovascular health study. Arch Neurol. 2009;66(3):336-342.

16. Chieffi S, La Marra M, Messina G, De Luca V, Messina A, Monda M. $\beta$-amyloid peptide in pathogenesis of Alzheimer's disease. Curr Topics Peptide Protein Res. 2011;12:65-69.

17. Chieffi S, La Marra M, Viggiano A, Messina G, De Luca V. Monda M. Caffeine protection against $\beta$-amyloid peptide toxicity in Alzheimer's disease. Current Topics in Peptide and Protein Research. 2011;12:71-75.

18. Raji CA, Ho AJ, Parikshak NN, et al. Brain structure and obesity. Hum Brain Mapp. 2010;31:353-364.

19. Gustafson D, Lissner L, Bengtsson C, Bjorkelund C, Skoog I. A 24-year follow-up of body mass index and cerebral atrophy. Neurology. 2004;63:1876-1881.

20. Ho AJ, Raji CA, Becker JT, et al.; Cardiovascular Health Study, ADNI. Obesity is linked with lower brain volume in $700 \mathrm{AD}$ and MCI patients. Neurobiol Aging. 2010;31(8):1326-1339.

21. Pannacciulli N, Del Parigi A, Chen K, Le DS, Reiman EM. Tataranni PA. Brain abnormalities in human obesity: a voxel-based morphometric study. Neuroimage. 2006;31:1419-1425.

22. Jagust W, Harvey D, Mungas D, Haan M. Central obesity and the aging brain. Arch Neurol. 2005;62(10):1545-1548.

23. Ward MA, Carlsson CM, Trivedi MA, Sager MA, Johnson SC. The effect of body mass index on global brain volume in middle-aged adults: a cross sectional study. BMC Neurol. 2005;5:23.

24. Gorospe EC, Dave JK. The risk of dementia with increased body mass index. Age Aging. 2007;36(1):23-29.

25. Taki Y, Kinomura S, Sato K, et al. Relationship between body mass index and gray matter volume in 1,428 healthy individuals. Obesity (Silver Spring). 2008;16:119-124.

26. Debette S, Seshadri S, Beiser A, et al. Midlife vascular risk factor exposure accelerates structural brain aging and cognitive decline. Neurology. 2011;77(5):461-468.

27. Messina G, Palmieri F, Monda V, et al. Exercise causes muscle Glut4 translocation in an insulin-independent manner. Biol Med. 2015;7:006.

28. Messina G, Viggiano A, Tafuri D, et al. Role of orexin in obese patients in the intensive care unit. J Anesth Clin Res. 2014;5:1000395.

29. Jack CR Jr, Petersen RC, Xu Y, et al. Rates of hippocampal atrophy correlate with change in clinical status in aging and AD. Neurology. 2000;55:484-489.

30. Raji CA, Lopez OL, Kuller LH, Carmichael OT, Becker JT. Age, Alzheimer disease, and brain structure. Neurology. 2009;73: 1899-1905.

31. Chieffi S, Messina G, La Marra M, et al. Distractor interference in visual motor tasks. In: Costa A, Villalba E, editors. Horizon in Neuroscience Research. 2014;13:151-160.

32. Elias MF, Beiser A, Wolf PA, Au R, White RF, D'Agostino RB. The preclinical phase of alzheimer disease: a 22-year prospective study of the Framingham Cohort. Arch Neurol. 2000;57(6):808-813.

33. Amieva H, Jacqmin-Gadda H, Orgogozo JM, et al. The 9 year cognitive decline before dementia of the Alzheimer type: a prospective population-based study. Brain. 2005;128(Pt 5):1093-1101.

34. Iavarone A, Patruno M, Galeone F, Chieffi S, Carlomagno S. Brief report: error pattern in an autistic savant calendar calculator. J Autism Dev Disord. 2007;37(4):775-779.

35. Francavilla G, Abrignani MG, Braschi A, et al. [Physical exercise and sport activities in patients with and without coronary heart disease]. Monaldi Arch Chest Dis. 2007;68(2):87-95. Italian.

36. Francavilla VC, Abricnani M, Braschi A, Francavilla C. Utility of QT dispersion in sports medicine. Medicina Dello Sport. 2008;61:477-485.

37. Chieffi S, Messina G, Villano I, et al. Exercise influence on hippocampal function: possible involvement of Orexin-A. Front Physiol. 2017;8:85

38. Serrano-Pozo A, Frosch MP, Masliah E, Hyman BT. Neuropathological alterations in Alzheimer disease. Cold Spring Harb Perspect Med. 2011;1:a006189.

39. Mrak RE. Alzheimer-type neuropathological changes in morbidly obese elderly individuals. Clin Neuropathol. 20091;28;40-45. 
40. Lee YH, Martin JM, Maple RL, Tharp WG, Pratley RE. Plasma amyloid-beta peptide levels correlate with adipocyte amyloid precursor protein gene expression in obese individuals. Neuroendocrinology. 2009;90(4):383-390.

41. Jahangiri A, Wilson PG, Hou TF, Brown A, King VL, Tannock LR. Serum amyloid A is found on ApoB-containing lipoproteins in obese humans with diabetes. Obesity (Silver Spring). 2013;21(5): 993-996.

42. Moroz N, Tong M, Longato L, Xu H, de la Monte SM. Limited Alzheimer-type neurodegeneration in experimental obesity and type 2 diabetes mellitus. J Alzheimers Dis.2008;15:29-44.

43. Anstey N, Cherbuin M, Budge M, Young J. Body mass index in midlife and late-life as a risk factor for dementia: a meta-analysis of prospective studies. Obes Rev. 2011;12:426-437.

44. Luchsinger JA, Patel B, Tang MX, Schupf N, Mayeux R. Measures of adiposity and dementia risk in elderly persons. Arch Neurol. 2007;64:392-398.

45. Nguyen JC, Killcross AS, Jenkins TA. Obesity and cognitive decline: role of inflammation and vascular changes. Front Neurosci. 2014;8:375.

46. Ballabh P, Braun A, Nedergaard M. The blood-brain barrier: an overview: structure, regulation, and clinical implications. Neurobiol Dis. 2004;16:1-13

47. Skoog I, Wallin A, Fredman P, et al. A population study on blood-brain barrier function in 85-year-olds: relation to Alzheimer's disease and vascular dementia. Neurology. 1998;50(4):966-971.

48. Gustafson DR, Karlsson C, Skoog I, Rosengren L, Lissner L, Blennow $\mathrm{K}$. Mid-life adiposity factors relate to blood-brain barrier integrity in late life. J Intern Med. 2007;262:643-650.

49. Odegaard JI, Chawla A. Pleiotropic actions of insulin resistance and inflammation in metabolic homeostasis. Science. 2013;339(6116): 172-177.

50. Hotamisligil GS, Shargill NS, Spiegelman BM. Adipose expression of tumor necrosis factor-alpha: direct role in obesity-linked insulin resistance. Science. 1993;259(5091):87-91.

51. Visser M, Bouter LM, McQuillan GM, Wener MH, Harris TB. Elevated $\mathrm{C}$ reactive protein levels in overweight and obese adults. JAMA. 1999;282(22):2131-2135.

52. Yudkin JS, Stehouwer CD, Emeis JJ, Coppack SW. C-reactive protein in healthy subjects: associations with obesity, insulin resistance, and endothelial dysfunction: a potential role for cytokines originating from adipose tissue? Arterioscler Thromb Vasc Biol. 1999;19(4): 972-978.

53. Ouchi N, Parker JL, Lugus JJ, Walsh K. Adipokines in inflammation and metabolic disease. Nat Rev Immunol. 2011;11(2):85-97.

54. Miller AA, Spencer SJ. Obesity and neuroinflammation: a Pathway to cognitive impairment. Brain Behav Immun. 2014;42:10-21.

55. Pradhan AD, Manson JE, Rifai N, Buring JE, Ridker PM. C-reactive protein, interleukin 6 , and risk of developing type 2 diabetes mellitus. JAMA. 2001;286(3):327-334.

56. Bruun JM, Pedersen SB, Kristensen K, Richelsen B. Effects of proinflammatory cytokines and chemokines on leptin production in human adipose tissue in vitro. Mol Cell Endocrinol. 2002;190(1-2): 91-99.

57. Trayhurn P, Wood IS. Adipokines: inflammation and the pleiotropic role of white adipose tissue. Br J Nutr. 2004;92(3):347-355.

58. Yaffe K. Metabolic syndrome and cognitive decline. Curr Alzheimer Res. 2007;4(2):123-126.

59. Hassing et al. Overweight in midlife and risk of dementia: a 40-year follow-up study. Int J Obes (Lond). 2009;33(8):893-898.

60. McElroy SL, Kotwal R, Malhotra S, Nelson EB, Keck PE, Nemeroff $\mathrm{CB}$. Are mood disorders and obesity related? A review for the mental health professional. J Clin Psychiatry. 2004;65(5):634-651.

61. Onyike CU, Crum RM, Lee HB, Lyketsos CG, Eaton WW. Is obesity associated with major depression? Results from the Third National Health and Nutrition Examination Survey. Am J Epidemiol. 2003;158(12):1139-1147.
62. Amann B, Mergl R, Torrent C, et al. Abnormal temperament in patients with morbid obesity seeking surgical treatment. $J$ Affect Disord. 2009;118(1-3):155-160.

63. Glinski J, Wetzler S, Goodman E. The psychology of gastric bypass surgery. Obes Surg. 2001;11:581-588.

64. Hsu LK, Benotti PN, Dwyer J, et al. Nonsurgical factors that influence the outcome of bariatric surgery: a review. Psychosomat Med. 1998;60(3):338-346.

65. Kolotkin RL, Crosby RD, Pendleton R, Stong M, Gress RE, Adams T. Healthrelated quality of life in patients seeking gastric bypass surgery vs non-treatment-seeking controls. Obes Surg. 2003;13(3):371-377.

66. Carpenter KM, Hasin DS, Allison DB, Faith MS. Relationships between obesity and DSM-IV major depressive disorder, suicide ideation, and suicide attempts: results from a general population study. Am J Public Health. 2000;90(2):251-257.

67. Goodman E, Whitaker RC. A prospective study of the role of depression in the development and persistence of adolescent obesity. Pediatrics. 2002;110(3):497-504.

68. Richardson LP, Davis R, Poulton R, et al. A longitudinal evaluation of adolescent depression and adult obesity. Arch Pediatr Adolesc Med. 2003;157(8):739-745.

69. Maddi SR, Fox SR, Khoshaba DM, Harvey RH, Lu JL, Persico M. Reduction in psychopathology following bariatric surgery for morbid obesity. Obes Surg. 2001;11(6):680-685.

70. Black DW, Goldstein RB, Mason EE. Prevalence of mental disorder in 88 morbidly obese bariatric clinic patients. Am J Psychiatry. 1992;149(2):227-234.

71. Papageorgiou GM, Papakonstantinou A, Mamplekou E, Terzis I, Melissas J. Pre- and postoperative psychological characteristics in morbidly obese patients. Obes Surg. 2002;12(4):534-539.

72. Assari SJ. Association between obesity and depression among American Blacks: role of ethnicity and gender. J Racial Ethn Health Disparities.2014;1:36.

73. Kim JY, Chang HM, Cho JJ, Yoo SH, Kim SY. Relationship between obesity and depression in the Korean working population. J Korean Med Sci. 2010;25(11):1560-1567.

74. Bramanti V, Bronzi D, Tomassoni D, et al. Effect of choline-containing phospholipids on transglutaminase activity in primary astroglial cell cultures. Clin Exp Hypertens. 2008;30:798-807.

75. Bramanti V, Grasso S, Tomassoni D, et al. Effect of growth factors and steroid hormones on heme oxygenase and cyclin D1 expression in primary astroglial cell cultures. $J$ Neurosci Res. 2015;93:521-529.

76. Bramanti V, Tomassoni D, Grasso S, et al. Cholinergic precursors modulate the expression of heme oxigenase-1, p21 during astroglial cell proliferation and differentiation in culture. Neurochem Res. 2012;37:2795-2804.

77. Cacopardo B, Pinzone MR, Berretta S, et al. Localized and systemic bacterial infections in necrotizing pancreatitis submitted to surgical necrosectomy or percutaneous drainage of necrotic secretions. $B M C$ Surg. 2013;13 (Suppl 2):S50.

78. Viggiano A, Chieffi S, Tafuri D, et al. Laterality of a second player position affects lateral deviation of basketball shooting. J Sports Sci. 2014;32(1):46-52.

79. Viggiano A, Nicodemo U, Viggiano E, et al. Mastication overload causes an increase in $\mathrm{O} 2$ - production into the subnucleus oralis of the spinal trigeminal nucleus. Neuroscience. 2010;166(2):416-421.

80. Istvan J, Zavela K, Weidner G. Body weight and psychological distress in NHANES I. Int J Obes Relat Metlab Discord. 1992;16(12):999-1003.

81. Moscatelli F, Valenzano A, Petito A, et al. Relationship between blood lactate and cortical excitability between taekwondo atlete and non-athletes after hand-grip exercise. Somatosens Mot Res. 2016;33(2):137-144.

82. Messina G, Monda V, Moscatelli F, et al. Role of orexin system in obesity. Biol Med. 2015;7:248.

83. Ruberto M, Precenzano F, Parisi L, et al. Visuomotor integration skills in children affected by obstructive sleep apnea syndrome: a case-control study. Acta Medica Mediterranea. 2016;32:1659-1663. 
84. Roberts RE, Deleger S, Strawbridge WJ, Kaplan GA. Prospective association between obesity and depression: evidence from the Alameda County Study. Int J Obes. 2003;27(4):514-521.

85. Roccella M, Salerno M, Parisi L, et al. Borderline intellectual functioning and parental stress: an italian case-control study. Acta Medica Mediterranea. 2016;32:1762-1765.

86. Cerretani D, Bello S, Cantatore S, et al. Acute administration of 3,4-methylenedioxymethamphetamine (MDMA) induces oxidative stress, lipoperoxidation and TNF $\alpha$-mediated apoptosis in rat liver Pharmacol Res. 2011;64(5):517-527.

87. Turillazzi E, Greco P, Neri M, Pomara C, Riezzo I, Fineschi V. Anaphylactic latex reaction during anaesthesia: the silent culprit in a fatal case. Forensic Sci Int. 2008;179(1):e5-8.

88. Solfrizzi V, Panza F, Colacicco AM, et al; Italian Longitudinal Study on Aging Working Group. Vascular risk factors, incidence of MCI, and rates of progression to dementia. Neurology. 2004;63(10):1882-1891.

89. Gustafson DR, Backman K, Joas E, et al. 37 years of body mass index and dementia: observations from the prospective population study of women in Gothenburg, Sweden. J Alzheimers Dis. 2012;28:163-171.

90. Besser LM, Gill DP, Monsell SE, et al. Body mass index, weight change, and clinical progression in mild cognitive impairment and Alzheimer disease. Alzheimer Dis Assoc Disord. 2014;28:36-43.

91. Kivipelto M, Ngandu T, Fratiglioni L, et al. Obesity and vascular risk factors at midlife and the risk of dementia and Alzheimer disease. Arch. Neurol. 2005;62:1556-1560.

92. Whitmer RA, Gunderson EP, Quesenberry CP, Zhou J, Yaffe K. Body mass index in midlife and risk of Alzheimer disease and vascular dementia. Curr Alzheimer Res. 2007;4:103-109.

93. Cournot M, Marquie JC, Ansiau D, Martinaud C, Fonds H, Ferrieres J, Ruidavets JB. Relation between body mass index and cognitive function in healthy middle-aged men and women. Neurology. 2006;67(7):1208-1214

94. Yaffe K, Kanaya A, Lindquist K, et al. The metabolic syndrome, inflammation, and risk of cognitive decline. JAMA. 2004;292(18):2237-2242.

95. Elias MF, Elias PK, Sullivan LM, Wolf PA, D'Agostino RB. Lower cognitive function in the presence of obesity and hypertension: the Framingham heart study. Int J Obes Relat Metab Disord. 2003;27(2):260-268.

96. Gustafson DR, Backman K, Waern M, et al. Adiposity indicators and dementia over 32 years in Sweden. Neurology. 2009;73(19):1559-1566.

97. Buchman AS, Wilson RS, Bienias JL, Shah RC, Evans DA, Bennett DA. Change in body mass index and risk of incident Alzheimer disease. Neurology. 2005;65:892-897.

98. Stewart R, Masaki K, Xue QL, et al. A 32 year prospective study of change in body weight and incident dementia: the Honolulu-Asia aging study. Arch Neurol. 2005;62:55-60.

99. Nourhashemi F, Deschamps V, Larrieu S, et al. Body mass index and incidence of dementia: the PAQUID study. Neurology. 2003;60:117-119.

100. Freedman DM, Ron E, Ballard-Barbash R, Doody MM, Linet MS. Body mass index and all-cause mortality in a nationwide US cohort. Int J Obes (Lond). 2006;30(5):822-829.

101. Curtis JP, Selter JG, Wang Y, et al. The obesity paradox: body mass index and outcomes in patients with heart failure. Arch Intern Med. 2005;165:55-61.
102. Kalantar-Zadeh K, Abbott KC, Salahudeen AK, Kilpatrick RD, Horwich TB. Survival advantages of obesity in dialysis patients. $\mathrm{Am} \mathrm{J}$ Clin Nutr. 2005;82(3):909-910.

103. Johnson DK, Wilkins CH, Morris JC. Accelerated weight loss may precede diagnosis in Alzheimer disease. Arch Neurol. 2006;63(9): 1312-1317.

104. Yaffe K, Fiocco AJ, Lindquist K, et al. Predictors of maintaining cognitive function in older adults: the Health ABC study. Neurology. 2009;72(23):2029-2035.

105. Komulainen P, Lakka TA, Kivipelto M, et al. Metabolic syndrome and cognitive function: a population-based follow-up study in elderly women. Dement Geriatr Cogn Disord. 2007;23(1):29-34.

106. Sturman MT, Mendes de Leon CF, Bienias JL, Morris MC, Wilson RS, Evans DA. Body mass index and cognitive decline in a biracial community population. Neurology. 2008;70:360-367.

107. Hughes TF, Borenstein AR, Schofield E, Wu Y, Larson EB. Association between late-life body mass index and dementia: the Kame Project. Neurology. 2009;72:1741-1746.

108. Dahl AK, Lopponen M, Isoaho R, Berg S, Kivela SL. Overweight and obesity in old age are not associated with greater dementia risk. $\mathrm{J} \mathrm{Am}$ Geriatr Soc. 2008;56:2261-2266.

109. Deschamps V, Astier X, Ferry M, Rainfray M, Emeriau JP, BarbergerGateau P. Nutritional status of healthy elderly persons living in Dordogne, France, and relation with mortality and cognitive or functional decline. Eur J Clin Nutr. 2002;56(4):305-312.

110. Scarmeas N, Luchsinger JA, Schupf N, et al. Physical activity, diet, and risk of Alzheimer disease. JAMA. 2009;302:627-637.

111. West NA, Haan MN. Body adiposity in late life and risk of dementia or cognitive impairment in a longitudinal communitybased study. $J$ Gerontol A Biol Sci Med Sci. 2009;64(1):103-109.

112. Doruk H, Naharci MI, Bozoglu E, Isik AT, Kilic S. The relationship between body mass index and incidental mild cognitive impairment, Alzheimer's disease and vascular dementia in elderly. $J$ Nutr Health Aging. 2010;14(10):834-838.

113. Messina G, Di Bernardo G, Viggiano A, et al. Exercise increases the level of plasma orexin A in humans. J Basic Clin Physiol Pharmacol. 2016;27(6):611-616.

114. Villano I, Messina A, Valenzano A, et al. Basal Forebrain Cholinergic System and Orexin Neurons: effects on attention. Front Behav Neurosci. 2017;11:10.

115. Franco R, Zappavigna S, Gigantino V, et al. Urotensin II receptor determines prognosis of bladder cancer regulating cell motility/invasion. J Exp Clin Cancer Res. 2014;33:48.

116. Chieffi S, Iavarone A, Iaccarino L, et al. Age-related differences in distractor interference on line bisection. Exp Brain Res. 2014; 32(11):3659-3664.

117. Messina G, Viggiano A, Chieffi S, et al. Interaction between leptin and fat and its relationship to menopause. Curr Topics Peptide Protein Res. 2011;12:77-81.

118. Chieffi S, Villano I, Iavarone A, et al. Asymmetries of Visuospatial Attention in Schizophrenia. J Psychiatry. 2016;19:388.

119. Chieffi S, Iavarone A, La Marra M, et al. Memory for proprioceptive targets in bulimia nervosa. J Psychiatry. 2015;18:297.

Diabetes, Metabolic Syndrome and Obesity: Targets and Therapy

\section{Publish your work in this journal}

Diabetes, Metabolic Syndrome and Obesity: Targets and Therapy is an international, peer-reviewed open-access journal committed to the rapid publication of the latest laboratory and clinical findings in the fields of diabetes, metabolic syndrome and obesity research Original research, review, case reports, hypothesis formation, expert opinion and commentaries are all considered for publication. The manuscript management system is completely online and includes a very quick and fair peer-review system, which is all easy to use. Visit http://www.dovepress.com/testimonials.php to read real quotes from published authors. 